\title{
Soil physical and biological properties in an integrated crop-livestock system in the Brazilian Cerrado
}

\author{
João de Andrade Bonetti( ${ }^{(1)}$, Helder Barbosa Paulino(2), Edicarlos Damacena de Souza(3), \\ Marco Aurélio Carbone Carneiro(4) and Jeander Oliveira Caetano(5)
}

\begin{abstract}
(1)Instituto Federal do Paraná, Campus Palmas, Avenida Bento Munhoz da Rocha Neto, s/no, PRT-280, Trevo da Codapar, CEP 85555-000 Palmas, PR, Brazil. E-mail: agro.bonetti@gmail.com (2)Universidade Federal do Triângulo Mineiro, Rua Paranaíba, ํㅜ 1.229, CEP 38280-000 Iturama, MG, Brazil. E-mail: helderlino51@yahoo.com.br (3)Universidade Federal de Rondonópolis, Instituto de Ciências Agrárias e Tecnológicas, Rodovia Rondonópolis-Guiratinga, CEP 78735-910 Rondonópolis, MT, Brazil. E-mail: edicarlos@pq.cnpq.br (4)Universidade Federal de Lavras, Departamento de Ciência do Solo, Caixa Postal 3.037, CEP 37200-000 Lavras, MG, Brazil. E-mail: marcocarbone@dcs.ufla.br ${ }^{(5)}$ Centro Universitário UNA, Rua José de Carvalho, no 1.800, Setor Epaminondas, CEP 75805-132 Jataí, GO, Brazil. E-mail: jeandercaetano@gmail.com
\end{abstract}

Abstract - The objective of this work was to evaluate the soil physical and biological properties in an integrated crop-livestock system (ICLS), with or without cattle grazing, in different seasons. The experiment was carried out in the Cerrado biome, in Brazil, in a Rhodic Eutrudox. The treatments consisted of grazing areas (Urochloa ruziziensis) at $0.25,0.35$, and $0.45 \mathrm{~m}$ heights (with soybean cultivation after grazing) and of nongrazed areas. The ICLS had no negative effects on soil bulk density, total porosity, macroporosity, and microporosity. After ICLS implementation, the values of soil bulk density decreased, and those of soil macroporosity increased, in the grazed and nongrazed areas. However, after three years, bulk density and macroporosity were reestablished to values similar to those before ICLS implementation. Soil penetration resistance was higher in the ICLS, mainly at $0.00-0.05 \mathrm{~m}$ soil depth. After four years, ICLS promoted the increase of microbial biomass $\mathrm{C}$ and $\mathrm{N}$ and the reduction of the metabolic quotient. The microbial biomass carbon and the metabolic quotient were related to the weighted mean diameter. ICLS benefits to soil physical and biological properties are associated with adequate ICLS implementation, adequate grazing height $(0.35 \mathrm{~m})$, and maintenance of soil cover.

Index terms: animal traffic, no-tillage system, soil aggregation, soil compaction, soil microbial biomass, soil quality.

\section{Propriedades físicas e biólogicas do solo em um sistema de integração lavoura-pecuária no Cerrado brasileiro}

Resumo - O objetivo deste trabalho foi avaliar as propriedades físicas e biológicas em um sistema de integração lavoura-pecuária (ILP), com ou sem pastejo, em diferentes safras. $\mathrm{O}$ experimento foi realizado no bioma Cerrado, no Brasil, em um Latossolo Vermelho distroférrico típico. Os tratamentos consistiram de áreas de pastejo (Urochloa ruziziensis) a 0,25, 0,35 e 0,45 $\mathrm{m}$ de altura (com cultivo de soja após o pastejo) e de áreas sem pastejo. O sistema ILP não teve efeitos negativos sobre densidade do solo, porosidade total, macroporosidade e microporosidade. Após a implementação do sistema ILP, os valores de densidade do solo diminuíram e os de macroporosidade aumentaram, nas áreas pastejadas e não pastejadas. No entanto, após três anos, a densidade e a macroporosidade foram reestabelecidas a valores similares aos anteriores à implementação do sistema ILP. A resistência do solo à penetração foi maior no sistema ILP, principalmente à profundidade de $0,00-0,05 \mathrm{~m}$ do solo. Após quatro anos, o sistema ILP promoveu o aumento do $\mathrm{C}$ e do $\mathrm{N}$ da biomassa microbiana e a redução do quociente metabólico. O carbono da biomassa microbiana e o quociente metabólico relacionaram-se ao diâmetro médio ponderado. Os benefícios do sistema ILP às propriedades físicas e biológicas do solo estão associados à implementação adequada do sistema ILP, à altura apropriada de pastejo $(0,35 \mathrm{~m})$ e à manutenção da cobertura do solo.

Termos para indexação: tráfego animal, sistema plantio direto, agregação do solo, compactação do solo, biomassa microbiana do solo, qualidade do solo.

\section{Introduction}

Different systems of soil management directly impact the Brazilian Cerrado agriculture. The conventional system of agricultural management (plowing and harrowing) and the low-plant diversity are the primary factors that have contributed to soil quality reduction. Moreover, extensive agricultural crop systems with low technological investment have led to soil degradation in livestock areas.

The main consequences of the intensive soil exploitation are the increase of soil compaction and 
erosion, and the reduction of soil organic matter (Landers et al., 2013), which are aggravated by the absence of fertilization and liming of forage and grain-crop areas (Lima et al., 2011). These factors, over the years, have reduced the yield capacity, increasing the production costs and, consequently, reduced the profitability of rural properties (Freitas \& Landers, 2014).

Theintroduction of grain crops with aciditycorrection and fertilization in no-tillage systems (NTS) has been confirmed to be an efficient alternative to improve soil quality. The NTS reduces soil mobilization and maintain the soil covered for the whole year. This fact increases the soil organic $\mathrm{C}$ content, which is important for improving soil physical, chemical, and biological properties (Corbeels et al., 2016). However, the NTS has been shown to be ineffective in maintaining crop rotation due to the higher economic profitability of soybean and maize crops, which, together with the intense use of machinery, restarted soil degradation (Landers et al., 2013; Freitas \& Landers, 2014).

At the beginning of the 1990s, the evolution of the NTS reactivated the integration of annual cropping with livestock production (Freitas \& Landers, 2014). From that time onwards the integrated crop-livestock system (ICLS) was boosted in Brazil (Carvalho et al., 2014). ICLS is defined as a system that aims at achieving synergism and emergent properties resulting from soil-plant-animal-atmosphere interactions of areas that integrate animal and crop exploitation (Moraes et al., 2014a), differing from NTS by animal grazing. Therefore, the improvement of soil quality in ICLS depends, particularly, on the adequate management of animals. This fact was reported by Martins et al. (2015) in Southern Brazil, where intense grazing at $0.10 \mathrm{~m}$ height resulted in the degradation of the soil physical, chemical, and biological properties. The same fact was not observed for moderate grazing, with grazing height between 0.2 and $0.3 \mathrm{~m}$. The correct management of grazing height can increase soil macroporosity and total porosity (Bonetti et al., 2015), soil aggregation, soil aggregate stability (Loss et al., 2011), and biological diversity (Franzluebbers \& Stuedemann, 2015).

The benefits of ICLS are linked to the increase of the soil organic matter by the incorporation of plant biomass (shoot and roots) and animal residues (Franzluebbers \& Stuedemann, 2015). This fact is evident in systems that use brachiaria due to the high-biomass production, which can reach more than
$15 \mathrm{Mg} \mathrm{ha} \mathrm{h}^{-1}$ (shoots and roots) with $0.35 \mathrm{~m}$ grazing height, consequently increasing soil aggregation (Loss et al., 2011; Bonetti et al., 2015). The addition of organic matter and the increase of soil aggregation in moderate grazing systems also influence the microbial biomass carbon, according to Souza et al. (2010b), who reported that $0.2 \mathrm{~m}$ grazing height maintained the soil biological quality, whereas a $0.1 \mathrm{~m}$ grazing height decreased it, in a study in Southern Brazil. This result is due to the increase of microorganisms in the soil in ICLS, where feces and urine of the animals serve as readily-available, highly-nutritious food (Clegg, 2006), which is important for soil aggregation and protection of the organic matter within the macroaggregates against the attack of microorganisms.

In this sense, studies should be developed to understand the effects of ICLS using different grazing heights, especially those converted from degraded areas, as the reduced (or moderate) grazing of Urochloa ruziziensis in the Cerrado biome is not considered as negatively affecting the physical and biological properties of the soil. In fact, it may contribute to recover degraded areas over the years.

The objective of this work was to evaluate the physical and biological properties of a Rhodic Eutrudox in an integrated crop-livestock system, with or without cattle grazing, at different seasons.

\section{Materials and Methods}

The work was carried out in the experimental area of the Universidade Federal de Goiás, in the municipality of Jataí, in the state of Goiás, Brazil $\left(17^{\circ} 56^{\prime} 57^{\prime \prime} \mathrm{S}, 51^{\circ} 43^{\prime} 18^{\prime \prime} \mathrm{W}\right)$. The climate of the region is classified as type Aw (Köppen-Geiger), with rainy summer (October-April) and dry winter (MaySeptember). The annual average precipitation is 1,600 $\mathrm{mm}$, and the average air temperature is $22{ }^{\circ} \mathrm{C}$. The soil is classified as a Latossolo Vermelho distroférrico típico (Santos et al., 2013a), i.e., a Rhodic Eutrudox, with $419 \mathrm{~g} \mathrm{~kg}^{-1}$ clay, $355 \mathrm{~g} \mathrm{~kg}^{-1}$ silt, and $226 \mathrm{~g} \mathrm{~kg}^{-1}$ sand, with slightly rolling relief, at $800 \mathrm{~m}$ altitude. The chemical and granulometric properties, evaluated before the implementation of the experiment, showed the following: $\mathrm{pH} \mathrm{H}_{2} \mathrm{O}, 5.2 ; \mathrm{P}, 1.4 \mathrm{mg} \mathrm{dm}^{-3}$; $\mathrm{Ca}^{2+}, 1.38$ $\mathrm{cmol}_{\mathrm{c}} \mathrm{dm}^{-3} ; \mathrm{Mg}^{2+}, 1.64 \mathrm{cmol}_{\mathrm{c}} \mathrm{dm}^{-3} ; \mathrm{K}^{+}, 0.19 \mathrm{cmol}_{\mathrm{c}} \mathrm{dm}^{-3}$; $\mathrm{Al}^{3+}, 0.2 \mathrm{cmol}_{\mathrm{c}} \mathrm{dm}^{-3}$; sum of bases, $3.21 \mathrm{cmol}_{\mathrm{c}} \mathrm{dm}^{-3}$; 
cation exchange capacity, $9.35 \mathrm{cmol}_{c} \mathrm{dm}^{-3}$; and base saturation, $35.6 \%$.

The experimental area had been conducted for 20 years with Urochloa decumbens, intensely grazed by dairy cattle (mean of 5 animal unit ha-1), without fertilizer application or soil fertility correction. In 2008, liming was carried out by applying $2.5 \mathrm{Mg} \mathrm{ha}^{-1}$ dolomitic limestone, with $80 \%$ PRNT to raise the base saturation to $60 \%$, which was incorporated to the soil with one plowing and two harrowings to implement the integrated crop-livestock system (ICLS) that began to be conducted as NTS.

In the summer of each season (years 2008/2009, 2009/2010, 2010/2011, and 2011/2012), soybean was cultivated a spacing of $0.45 \mathrm{~m}$ apart, with an approximate population of 340,000 plants per $\mathrm{ha}^{-1}$. Fertilization was carried out with $7 \mathrm{~kg} \mathrm{ha}^{-1} \mathrm{~N}, 63 \mathrm{~kg} \mathrm{ha}^{-1} \mathrm{P}_{2} \mathrm{O}_{5}$, and $63 \mathrm{~kg} \mathrm{ha}^{-1} \mathrm{~K}_{2} \mathrm{O}$. Urochloa ruziziensis $\left(10 \mathrm{~kg} \mathrm{ha}^{-1}\right.$ and $65 \%$ pure germinating seed) was sown in the winter of each year, with the application of $150 \mathrm{~kg} \mathrm{ha}^{-1} \mathrm{~N}$ in the form of urea 45 days after sowing. In the harvest of 2011/2012, dolomitic limestone was applied at $2.3 \mathrm{Mg} \mathrm{ha}^{-1}$; PRNT of $80 \%$ was reapplied in the total area, on the surface, without incorporation.

The soil management systems consisted of: ICLS with $0.25 \mathrm{~m}$ grazing height; ICLS with $0.35 \mathrm{~m}$ grazing height, predefined as the adequate grazing height for soil physical properties (Bonetti et al., 2015); ICLS with $0.45 \mathrm{~m}$ grazing height; and nongrazed area (NG), with brachiaria as cover crop. Each experimental plot had a 2.0 ha area, in a randomized block design in a splitplot arrangement, considering the treatments as the main plot, and the seasons as the split plots, with three replicates. The winter grazing height was controlled by the entry and exit of animals, and it was monitored every 14 days with a sward stick (Jenquip, model SS400M, Auckland, New Zealand), based on the methodology of Barthram (1985), with the determination of 50 points per plot. Grazing was performed by female cattle with an average of $450 \mathrm{~kg}$ live weight, beginning in July of each year, when forage reached $4,000 \mathrm{~kg} \mathrm{ha}^{-1}$ mean accumulation of dry matter and had been grazed for approximately 120 days.

Soil bulk density, total porosity, macroporosity, and microporosity were determined by soil samples with preserved structure, collected at four different seasons, as follows: before soil mobilization and experiment implementation, in November 2008, corresponding to the $2008 / 2009$ harvest; after brachiaria cultivation and grazing, in November 2011, corresponding to the 2010/2011 harvest (post-brachiaria cultivation year 2010/2011); after soybean cultivation, in April 2012 , corresponding to the $2011 / 2012$ harvest (postsoybean cultivation years 2011/2012); and after brachiaria cultivation and grazing, in November 2012 , corresponding to the $2011 / 2012$ harvest (postbrachiaria cultivation year 2011/2012). Soil samples were collected at three soil depths $(0-0.05,0.05-0.1$, and 0.1-0.2 m), using an auger (Uhland type, Soil Control, model TU-Uhland, São Paulo, SP, Brazil), and metallic rings $\left(98 \mathrm{~cm}^{-3}\right)$, with five replicates per plot. Soil bulk density was determined by the relation between the dry soil and the total volume of the collected soil. Soil macroporosity was determined in a tension table at $-6 \mathrm{kPa}$ (Donagema et al., 2011).

Trenches were dug to determine the aggregate stability, and $0.1 \mathrm{~m}$ wide intact samples were collected at $0-0.05,0.05-0.1$, and $0.1-0.2 \mathrm{~m}$ soil depth, in the post-brachiaria cultivation year of 2010/2011, postsoybean cultivation year 2011/2012, and post-brachiaria cultivation year 2011/2012, respectively. Samples were wrapped in PVC film and transported in styrofoamboxes to prevent alterations in their structure. Afterward, the samples were broken, respecting the weakness points (approximately $9 \mathrm{~mm}$ ), then they were air dried, and the wet aggregation was determined (Tisdall et al., 1978; Silva \& Mielniczuk, 1997). After wet sieving, the classes of aggregates were obtained $(>4.76,4.76-$ 2.0, 2.0-1.0, 1.0-0.5, 0.5-0.25, and $<0.25 \mathrm{~mm}$ ). From these data, the weighted mean diameter (WMD) was determined according to the following equation:

$$
\mathrm{WMD}=\sum_{(\mathrm{i}=1)}^{\mathrm{n}}(\mathrm{xi} \times \mathrm{wi}),
$$

in which: wi is the proportion (\%) of each class in relation to the total; and xi is the mean diameter of the respective classes $(\mathrm{mm})$.

The soil penetration resistance (PR) was determined in the following cultivations: post-brachiaria cultivation year 2010/2011; post-soybean cultivation year 2011/2012; and post-brachiaria cultivation year 2011/2012. Data were collected using a digital penetrometer (Falker, model PLG1020, Porto Alegre, $\mathrm{RS}$, Brazil), with a $30^{\circ}$ angle cone, and a $130 \mathrm{~mm}^{2}$ base area, according to the ASAE S313.3 standard (Asabe, 2010). A total of 66 points were measured in each

Pesq. agropec. bras., Brasília, v.53, n.11, p.1239-1247, Nov. 2018 DOI: $10.1590 / \mathrm{S} 0100-204 \mathrm{X} 2018001100006$ 
grazed and nongrazed treatment $(0-0.05,0.05-0.1$, and 0.1-0.2 m soil depths), and soil volumetric moisture was determined (Donagema et al., 2011).

To evaluate the effects of management systems on soil biology, the soil samples were collected in 2012 (post-brachiaria cultivation year 2011/2012) at 0-0.1 m soil depth. Soil respiration was determined by the capture of $\mathrm{CO}_{2}$ using $\mathrm{NaOH}$ after soil incubation for 72 hours (Alef \& Nanninpieri, 1995). The microbial biomass carbon was determined by the fumigationextraction technique, proposed by Vance et al. (1987), and the microbial biomass nitrogen was determined by the method of Brookes (1995). The metabolic quotient was expressed by the relation of soil respiration and microbial biomass C (Anderson \& Domsch, 1993), and the microbial quotient was expressed by the ratio of the microbial biomass $\mathrm{C}$ and the total organic $\mathrm{C}$ (Brookes, 1995).

Data for soil bulk density, total porosity, macroporosity, microporosity, penetration resistance, and aggregation were subjected to the analysis of variance, comparing the ICLS $(0.35 \mathrm{~m}$ grazing height) with the nongrazed areas (using brachiaria as cover crop) between and within the evaluated season. When the analysis was significant, the Tukey's test was applied at 5\% probability. The microbiological properties were compared between the ICLS treatments with grazing heights $(0.25,0.35$, and $0.45 \mathrm{~m})$ and the nongrazed area. The use of different grazing heights for the biological properties occurred due to the lack of knowledge on which grazing height would be appropriate. The following statistical model was used:

$$
\begin{aligned}
Y_{i j k}= & \mu+B_{i}+A_{j}+\operatorname{error} a(i, j)+C_{k}+\operatorname{error} b(i, k) \\
& +A C_{j k}+\operatorname{error} c(i, j, k),
\end{aligned}
$$

in which: $\mathrm{B}$ represents the blocks $(\mathrm{i}=1,2,3)$; A represents the seasons $(\mathrm{j}=1,2,3,4)$; and $\mathrm{C}$ is the grazing height $(\mathrm{k}=1,2,3)$.

A cluster analysis was performed using the complete linkage method, from the Euclidean distance, to describe the similarity between the studied systems, using the PAST statistical software (Hammer et al., 2001).

\section{Results and Discussion}

Total porosity ranged from 0.45 to $0.62 \mathrm{~m}^{3} \mathrm{~m}^{-3}$, and microporosity, from 0.30 to $0.43 \mathrm{~m}^{3} \mathrm{~m}^{-3}$, with no difference between treatments and season. Soil bulk density (BD) had alterations up to $0.1 \mathrm{~m}$ soil depth between the evaluated seasons, and had no alterations in the comparison between the ICLS treatment with $0.35 \mathrm{~m}$ grazing height and the nongrazed area (with brachiaria as cover crop) (Table 1). The BD values were higher at the beginning of the study in 2008, with a reduction after soil mobilization and cultivation in the year 2010/2011. However, the cultivation increased the BD, and after the grazing cycle in the year $2011 / 2012$, BD values were similar to those observed at the beginning of the experiment.

After the soil mobilization, a natural rearrangement of the particles and microaggregates occurred, altering the soil structure. This process was favored by plant biomass on the soil and brachiaria roots that dissipated the pressure imposed by the machinery and animal hooves (Martins et al., 2015). This fact suggests that the soil structure was properly reorganized, and was it not affected by the compaction of the tires and animal

Table 1. Soil bulk density and macroporosity in different seasons, in an integrated crop-livestock system (ICLS) and

\begin{tabular}{|c|c|c|c|c|}
\hline \multirow[t]{2}{*}{ Treatment } & \multicolumn{4}{|c|}{ Season } \\
\hline & $2008 / 2009$ & $\begin{array}{l}\text { Brachiaria } \\
2010 / 2011\end{array}$ & $\begin{array}{c}\text { Soybean } \\
2011 / 2012\end{array}$ & $\begin{array}{l}\text { Brachiaria } \\
2011 / 2012 \\
\end{array}$ \\
\hline & \multicolumn{4}{|c|}{ Soil bulk density $\left(\mathrm{Mg} \mathrm{m}^{-3}\right)$} \\
\hline & \multicolumn{4}{|c|}{ 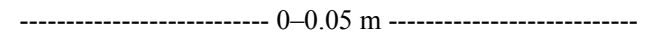 } \\
\hline ICLS & $1.22 \mathrm{aA}$ & $1.04 \mathrm{bA}$ & $1.14 \mathrm{aA}$ & $1.22 \mathrm{aA}$ \\
\hline NG & $1.20 \mathrm{aA}$ & $1.10 \mathrm{bA}$ & $1.17 \mathrm{abA}$ & $1.16 \mathrm{abA}$ \\
\hline & \multicolumn{4}{|c|}{ - } \\
\hline ICLS & $1.20 \mathrm{abA}$ & $1.12 \mathrm{bA}$ & $1.26 \mathrm{aA}$ & $1.28 \mathrm{aA}$ \\
\hline NG & $1.18 \mathrm{aA}$ & $1.17 \mathrm{aA}$ & $1.27 \mathrm{aA}$ & $1.25 \mathrm{aA}$ \\
\hline & \multicolumn{4}{|c|}{ 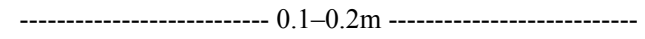 } \\
\hline ICLS & $1.11 \mathrm{aA}$ & $0.96 \mathrm{aA}$ & $1.13 \mathrm{aA}$ & $1.17 \mathrm{aA}$ \\
\hline \multirow[t]{3}{*}{ NG } & $1.17 \mathrm{aA}$ & $0.98 \mathrm{aA}$ & $0.81 \mathrm{aA}$ & $1.20 \mathrm{aA}$ \\
\hline & \multicolumn{4}{|c|}{ Macroporosity $\left(\mathrm{m}^{3} \mathrm{~m}^{-3}\right)$} \\
\hline & \multicolumn{4}{|c|}{ 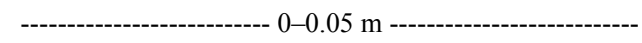 } \\
\hline ICLS & $0.09 \mathrm{cA}$ & $0.28 \mathrm{aA}$ & $0.21 \mathrm{bA}$ & $0.18 \mathrm{bA}$ \\
\hline NG & $0.09 \mathrm{bA}$ & $0.25 \mathrm{aA}$ & $0.20 \mathrm{aA}$ & $0.21 \mathrm{aA}$ \\
\hline & \multicolumn{4}{|c|}{ 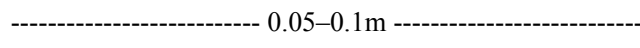 } \\
\hline ICLS & $0.10 \mathrm{cA}$ & $0.24 \mathrm{aA}$ & $0.18 \mathrm{abA}$ & $0.16 \mathrm{bcA}$ \\
\hline \multirow[t]{2}{*}{ NG } & $0.09 \mathrm{bA}$ & $0.21 \mathrm{aA}$ & $0.18 \mathrm{aA}$ & $0.18 \mathrm{aA}$ \\
\hline & \multicolumn{4}{|c|}{ 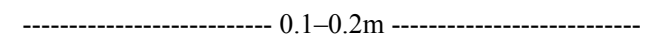 } \\
\hline ICLS & $0.16 \mathrm{Ac}$ & $0.30 \mathrm{Aa}$ & $0.23 \mathrm{bA}$ & $0.21 \mathrm{bA}$ \\
\hline $\mathrm{NG}$ & $0.12 \mathrm{Bc}$ & $0.26 \mathrm{Ba}$ & $0.24 \mathrm{abA}$ & $0.20 \mathrm{bA}$ \\
\hline
\end{tabular}
in a nongrazed area (NG) in the Cerrado biome ${ }^{(1)}$.

${ }^{(1)}$ Means followed by equal letters, lowercase in the rows and uppercase in the columns, do not differ by the Tukey's test, at $5 \%$ probability. Soil bulk density standard error: 0.021 , at $0.0-0.05 \mathrm{~m}$ soil depth; 0.026 , at $0.05-0.1 \mathrm{~m}$ soil depth; 0.113 , at $0.1-0.20 \mathrm{~m}$ soil depth. Standard error macroporosity: 0.015 , at $0.0-0.05 \mathrm{~m}$ soil depth; 0.015 , at $0.05-0.1 \mathrm{~m}$ soil depth; 0.010 , at $0.1-0.20 \mathrm{~m}$ soil depth. 
hooves. Root biomass production in ICLS is high; for instance, Bonetti et al. (2015) reported a production of $8.1 \mathrm{Mg} \mathrm{ha}^{-1}$ dry mass of brachiaria roots, and $2.67 \mathrm{Mg} \mathrm{ha}^{-1}$ dry mass of soybean root, which reduces soil compaction.

Macroporosity was altered in all the layers as a consequence of the season (Table 1). At the beginning of the experiment, in 2008, soil macroporosity was less than $0.10 \mathrm{~m}^{3} \mathrm{~m}^{-3}$. This value may affect plant development (Bengough et al., 2011) and may be the result of inadequate soil exploitation, with low-forage yield and high-animal load. However, macroporosity increased after soil mobilization and brachiaria cultivation (year 2010/2011) (Table 1). When comparing the management systems (with, or without grazing) within each season, soil macroporosity was higher in the grazed area after brachiaria cultivation (year 2010/2011), in the 0.1-0.2 $\mathrm{m}$ layer, than in the nongrazed one. This result is related to the greater root development up to $0.2 \mathrm{~m}$ depth, both by soybean and brachiaria in grazed areas. Grazing stimulates tillering and provides a greater development of the root system (Souza et al., 2010a; Santos et al., 2013b). This fact leads to a greater release of root exudates, which associated with the addition of residues (urine + feces) promotes a greater macropore distribution, as observed by Souza et al. (2010a). These changes improve the soil structure, leading to greater infiltration, aeration, and water storage (Franzluebbers et al., 2011).

The weighted mean diameter (WMD) of aggregates increased between seasons. The lowest WMD was observed in the post-brachiaria cultivation in 2010/2011, and the highest WMD was obtained in the post-soybean cultivation in 2011/2012 and in the post-brachiaria cultivation in 2011/2012, in all evaluated layers (Table 2). At $0.35 \mathrm{~m}$ grazing height, WMD increase was more evident at $0-0.05$ and $0.1-0.2 \mathrm{~m}$ soil depths, in the post-soybean cultivation. In the nongrazed area, WMD increase was more evident after the last harvest (year 2011/2012), at 0-0.05 $\mathrm{m}$ soil depth, and in the soybean cultivation at $0.05-0.1 \mathrm{~m}$ soil depth.

When comparing the value of aggregate stability (mean of $0.2 \mathrm{~m}$ ) in the year 2010/2011 with those in the year 2011/2012, a $15 \%$ increase is observed in the area with $0.35 \mathrm{~m}$ grazing height, and a $9 \%$ increase is verified in the nongrazed area. The higher-soil aggregate stability is a consequence of the organic matter increase (Jozefaciuk \& Czachor, 2014), both by the greater root development of the plants (Martins et al., 2015) and animal residues (feces and urine) that serve as readily-available food to soil microorganisms, which results in compounds that favor soil aggregation over time (Clegg, 2006; Martins et al., 2015). In the present work, the presence of grazing animals did not reduce soil aggregation after two grazing seasons. The increase of soil aggregation was crucial for the soil functional capacity, as it provides physical stability.

The changes of soil penetration resistance (PR) between the studied seasons occurred only at $0.1-0.2 \mathrm{~m}$ soil depth, with lower values of PR in the soybean cultivation in 2011-2012 (Table 2). The highest PR was observed in the grazing area ( $0.35 \mathrm{~m}$ height), in all layers, after soybean cultivation (2011/2012), and up to $0.1 \mathrm{~m}$ soil depth, after grazing (2011/2012). After cultivation (post-brachiaria cultivation in 2011/2012), differences were detected for PR at $0-0.05 \mathrm{~m}$ soil

Table 2. Weighted mean diameter and soil penetration resistance, at different seasons, in an integrated croplivestock system (ICLS) and in a nongrazed area (NG) in the Cerrado biome ${ }^{(1)}$.

\begin{tabular}{|c|c|c|c|}
\hline \multirow[t]{3}{*}{ Treatment } & \multicolumn{3}{|c|}{ Season } \\
\hline & Brachiaria & Soybean & Brachiaria \\
\hline & 2010/2011 & 2011/2012 & 2011/2012 \\
\hline & \multicolumn{3}{|c|}{ Weighted mean diameter $(\mathrm{mm})$} \\
\hline & & $-0-0.05 \mathrm{~m}$ & ------------ \\
\hline $\operatorname{ICLS}^{(2)}$ & $1.77 \mathrm{Ab}$ & 2.09Aa & $2.16 \mathrm{aA}$ \\
\hline NG & $1.87 \mathrm{Ab}$ & $1.85 \mathrm{Bb}$ & $2.20 \mathrm{aA}$ \\
\hline ICLS & $2.12 \mathrm{Aa}$ & $2.25 \mathrm{Aa}$ & 2.31Aa \\
\hline \multirow[t]{2}{*}{ NG } & $2.08 \mathrm{Ab}$ & $2.18 \mathrm{Aab}$ & $2.36 \mathrm{Aa}$ \\
\hline & & $-0.1-0.2 \mathrm{~m}$ & ------------ \\
\hline ICLS & 2.02Ac & $2.21 \mathrm{Ab}$ & $2.35 \mathrm{Aa}$ \\
\hline \multirow[t]{3}{*}{ NG } & 2.29AAa & $2.27 \mathrm{Aa}$ & $2.26 \mathrm{Aa}$ \\
\hline & \multicolumn{3}{|c|}{ Soil penetration resistance $(\mathrm{MPa})$} \\
\hline & & $-0-05 \mathrm{~m}$ & $165 a_{0}$ \\
\hline \multirow{2}{*}{ NG } & $1.46 \mathrm{Aa}$ & $\begin{array}{l}1.54 \mathrm{Aa} \\
1.34 \mathrm{Ba}\end{array}$ & $\begin{array}{l}1.65 \mathrm{Aa} \\
125 \mathrm{Ba}\end{array}$ \\
\hline & & $0.05-0.1 \mathrm{~m}$ & -1--1- \\
\hline ICLS & $1.69 \mathrm{Aa}$ & $1.80 \mathrm{Aa}$ & $1.78 \mathrm{Aa}$ \\
\hline \multirow[t]{2}{*}{ NG } & $1.62 \mathrm{Aa}$ & $1.48 \mathrm{Ba}$ & $1.61 \mathrm{Ba}$ \\
\hline & -------- & $-0.1-0.2 \mathrm{~m}$ & ---------- \\
\hline ICLS & 1.69Aa & $1.65 \mathrm{Aa}$ & $1.75 \mathrm{Aa}$ \\
\hline NG & $1.65 \mathrm{Aa}$ & $1.38 \mathrm{Bb}$ & $1.73 \mathrm{Aa}$ \\
\hline
\end{tabular}

(1)Means followed by equal letters, lowercase in the rows and uppercase in the columns, do not differ by the Tukey's test, at $5 \%$ probability. ${ }^{n s}$ Nonsignificant. Standard error for weighted mean diameter: 0.041, at $0.0-0.05 \mathrm{~m}$ soil depth; 0.064 , at $0.05-0.1 \mathrm{~m}$ soil depth; 0.033 , at $0.1-0.20 \mathrm{~m}$ soil depth. Standard error for soil penetration resistance: 0.052 , at $0.0-0.05 \mathrm{~m}$ soil depth; 0.046 , at $0.05-0.1 \mathrm{~m}$ soil depth; 0.058 , at $0.1-0.20 \mathrm{~m}$ soil depth. ${ }^{(2)}$ ICLS, with grazing height at $0.35 \mathrm{~m}$. 
depth, which may indicate alterations in the soil by animals trampling. No changes were observed in the soil moisture between seasons, and the observed means were: $0.228 \mathrm{~m}^{3} \mathrm{~m}^{-3}$ (post-brachiaria cultivation in $2010 / 2011$ ), $0.202 \mathrm{~m}^{3} \mathrm{~m}^{-3}$ (post-soybean cultivation in 2011/2012), and $0.273 \mathrm{~m}^{3} \mathrm{~m}^{-3}$ (post-brachiaria cultivation in 2011/2012) at $0-0.2 \mathrm{~m}$ soil depth.

The penetration resistance at $2 \mathrm{MPa}$ is usually used as a limiting value to root development (Lima et al., 2012). However, studies have shown great variations in function of soil-water potential (Bengough et al., 2011). Moraes et al. (2014b) evaluated a Rhodic Eutrudox in Southern Brazil, and confirmed PR at $2 \mathrm{MPa}$ as an adequate value for conventional tillage systems, and PR at 3.5 MPa as an inadequate value for NTS. In fact, alterations up to $0.05 \mathrm{~m}$ soil depth have not reduced yield in the summer crop (Martins et al., 2015).

After four years of soil mobilization, a highermicrobial biomass $\mathrm{C}$ and $\mathrm{N}$, a higher ratio of microbial biomass $\mathrm{C}$ and of soil total organic $\mathrm{C}$, and a lower-metabolic quotient in the grazed areas were observed than in the nongrazed area (Table 3). Basal respiration showed no differences between soil management systems. These changes indicate a higher microorganism activity, as well as raw material availability, and favorable humidity and temperature conditions for the development of microorganisms in grazing areas, which, unlike this study, were observed in ICLS by Franzluebbers et al. (2007) and Clegg (2006). Grazing animals may play an important role in microbial biomass due to several specific factors associated with the presence of cattle. Grazing animals add feces and urine to the soil, which change the rhizosphere exudation patterns, the botanical composition, and the soil structure and aeration owing to animals trampling (Clegg, 2006). Cattle urine increases respiration, $\mathrm{N}_{2} \mathrm{O}$ and $\mathrm{NO}_{2}$ emissions, and microbial biomass C (Lovell \& Jarvis, 1996).

The ratio of microbial biomass $\mathrm{C}$ and total organic $\mathrm{C}$ was higher in ICLS with grazing height between 0.25 and $0.45 \mathrm{~m}$, both compared with the nongrazed area. The increase of the metabolic quotient indicates a reduction of the necessary energy for the maintenance of the metabolic activity, in relation to the required energy for the synthesis of the biomass. The higher value of the $q \mathrm{CO}_{2}$, in the present work, is indicative of a stress condition in the microbial activity (Anderson $\&$ Domsch, 1993). Muniz et al. (2011) also observed that the replacement of degraded pastures by an ICLS increased the microbial population and decreased the environmental stress evaluated by the microbial biomass $\mathrm{C}$ and metabolic quotient, respectively. Moraes et al. (2014a) observed benefits of ICLS for soil biology, with an increase of the microbial activity at $0.2-0.3 \mathrm{~m}$ grazing height.

The evaluated attributes correlated to the weighted mean diameter of soil aggregates (WMD) (Table 4). The microbial biomass $\mathrm{C}$ and the metabolic quotient were strongly related to the WMD (Figure 1). The positive quadratic relation of the microbial biomass $\mathrm{C}$ with the WMD may be associated with the protection of the organic matter in aggregates with higher WMD. Jiang et al. (2011) showed that the distribution pattern of microbial biomass $\mathrm{C}$, associated with soil aggregates, was probably governed by the size of the aggregates, as observed in the present research (Figure $1 \mathrm{~A}$ ). The present work also corroborates Umer \& Rajab (2012), who stated that the microbial metabolic quotient was directly proportional to the decrease of soil aggregate stability (Figure $1 \mathrm{~B}$ ).

Season clustering analysis formed two large groups (group 1 consisted of the initial conditions in 2008/2009; group 2 consisted of all the other seasons)

Table 3. Microbial biomass carbon, microbial biomass nitrogen, basal respiration, metabolic quotient, and microbial quotient of a Rhodic Eutrudox, in an integrated crop-livestock system (ICLS) and in a nongrazed area (NG), in the Cerrado biome. ${ }^{(1)}$

\begin{tabular}{|c|c|c|c|c|c|}
\hline Management ${ }^{(2)}$ & $\begin{array}{c}\mathrm{MBC} \\
\left(\mu \mathrm{g} \mathrm{g} \mathrm{g}^{-1} \text { soil }\right) \\
\end{array}$ & $\begin{array}{c}\text { MBN } \\
\left(\mu \mathrm{g} \mathrm{N} \mathrm{g}^{-1} \text { soil }\right) \\
\end{array}$ & $\begin{array}{c}\mathrm{C}-\mathrm{CO}_{2} \\
\left(\mathrm{mg} \mathrm{CO}_{2} \mathrm{~g} \mathrm{~h}^{-1}\right) \\
\end{array}$ & $\begin{array}{l}q \mathrm{CO}_{2}\left(\mathrm{mg} \mathrm{CO}_{2} \mathrm{~g} \mathrm{~h}^{-1}\right. \\
\left.\mu \mathrm{g} \mathrm{C}_{\mathrm{g} \mathrm{soil}}{ }^{-1}\right) \times 10^{-3}\end{array}$ & $\begin{array}{c}\mathrm{BM} / \mathrm{COT} \\
(\%)\end{array}$ \\
\hline ICLS, P-25 & $818 \mathrm{a}$ & $4.0 \mathrm{a}$ & $19.8 \mathrm{a}$ & $24.2 \mathrm{~b}$ & $1.6 \mathrm{a}$ \\
\hline ICLS, P-35 & $781 \mathrm{ab}$ & $3.7 \mathrm{a}$ & $20.1 \mathrm{a}$ & $25.7 \mathrm{~b}$ & $1.4 \mathrm{~b}$ \\
\hline ICLS, P-45 & $876 a$ & $3.7 \mathrm{a}$ & $18.7 \mathrm{a}$ & $21.3 \mathrm{c}$ & $1.6 \mathrm{a}$ \\
\hline NG & $671 \mathrm{~b}$ & $2.5 \mathrm{~b}$ & $19.3 \mathrm{a}$ & $28.8 \mathrm{a}$ & $1.1 \mathrm{c}$ \\
\hline
\end{tabular}

${ }^{(1)}$ Means followed by equal letters in the columns, do not differ by the Tukey's test, at $5 \%$ probability. Mean data for the year 2012 after grazing, at $0-0.1$ $\mathrm{m}$ soil depth. $\mathrm{MBC}$, microbial biomass carbon; $\mathrm{MBN}$, microbial biomass nitrogen; $\mathrm{C}-\mathrm{CO}_{2}$, basal respiration; $q \mathrm{CO}_{2}$, metabolic quotient; $\mathrm{MB} / \mathrm{TOC}$, ratio of microbial biomass and total organic carbon. ${ }^{(2)} \mathrm{P} 25,0.25 \mathrm{~m}$ grazing height; $\mathrm{P} 35,0.35 \mathrm{~m}$ grazing height; $\mathrm{P} 45,0.45 \mathrm{~m}$ grazing height. 
Table 4. Simple linear correlation between soil properties of Rhodic Eutrudox, in an integrated crop-livestock system in the Cerrado biome ${ }^{(1)}$.

\begin{tabular}{lc}
\hline Variable & $\mathrm{R}^{2}$ \\
\hline Soil bulk density x weighted mean diameter & $0.56^{\mathrm{ns}}$ \\
Macroporosity x weighted mean diameter & $0.99^{* *}$ \\
Penetration resistance x weighted mean diameter & $0.96^{* *}$ \\
Microbial biomass carbon x weighted mean diameter & $0.99^{* *}$ \\
Microbial biomass nitrogen x weighted mean diameter & $0.99^{* *}$ \\
Metabolic quotient x weighted mean diameter & $0.99^{* *}$ \\
Basal respiration x weighted mean diameter & $0.95^{* *}$ \\
\hline
\end{tabular}

${ }^{(1)}$ Correlation by t-test. **Significant at $1 \%$ probability. ${ }^{\text {ns Nonsignificant. }}$
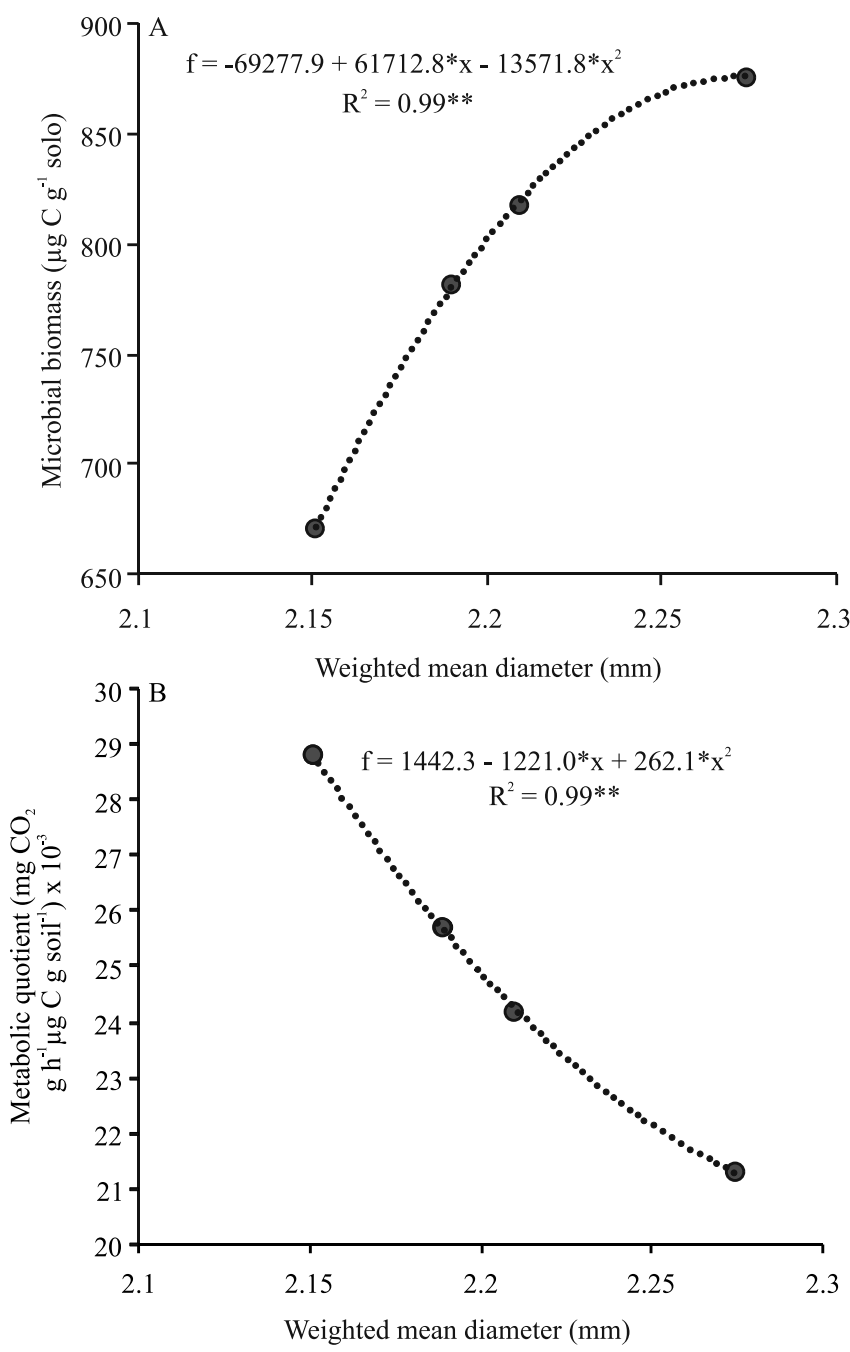

Figure 1. Ratio of weighted mean diameter and microbial biomass carbon (A) and metabolic quotient (B) of the soil, in an integrated crop-livestock system, in the Cerrado biome. Data of weighted mean diameter of the year 2011/2012, at $0-0.1 \mathrm{~m}$ soil depth. ${ }^{* *}$ Significant at $1 \%$ probability, by the t-test. for soil physical properties (Figure 2). These two groups had no similarity between each other, as their linkage distance was maximal (100\%). The second group allocated the post-brachiaria cultivation year 2011/2012, post-soybean cultivation year 2011/2012, and post-brachiaria cultivation year 2010/2011. This group was divided into two subgroups that presented a $96.5 \%$ linkage distance, that is, a low similarity.

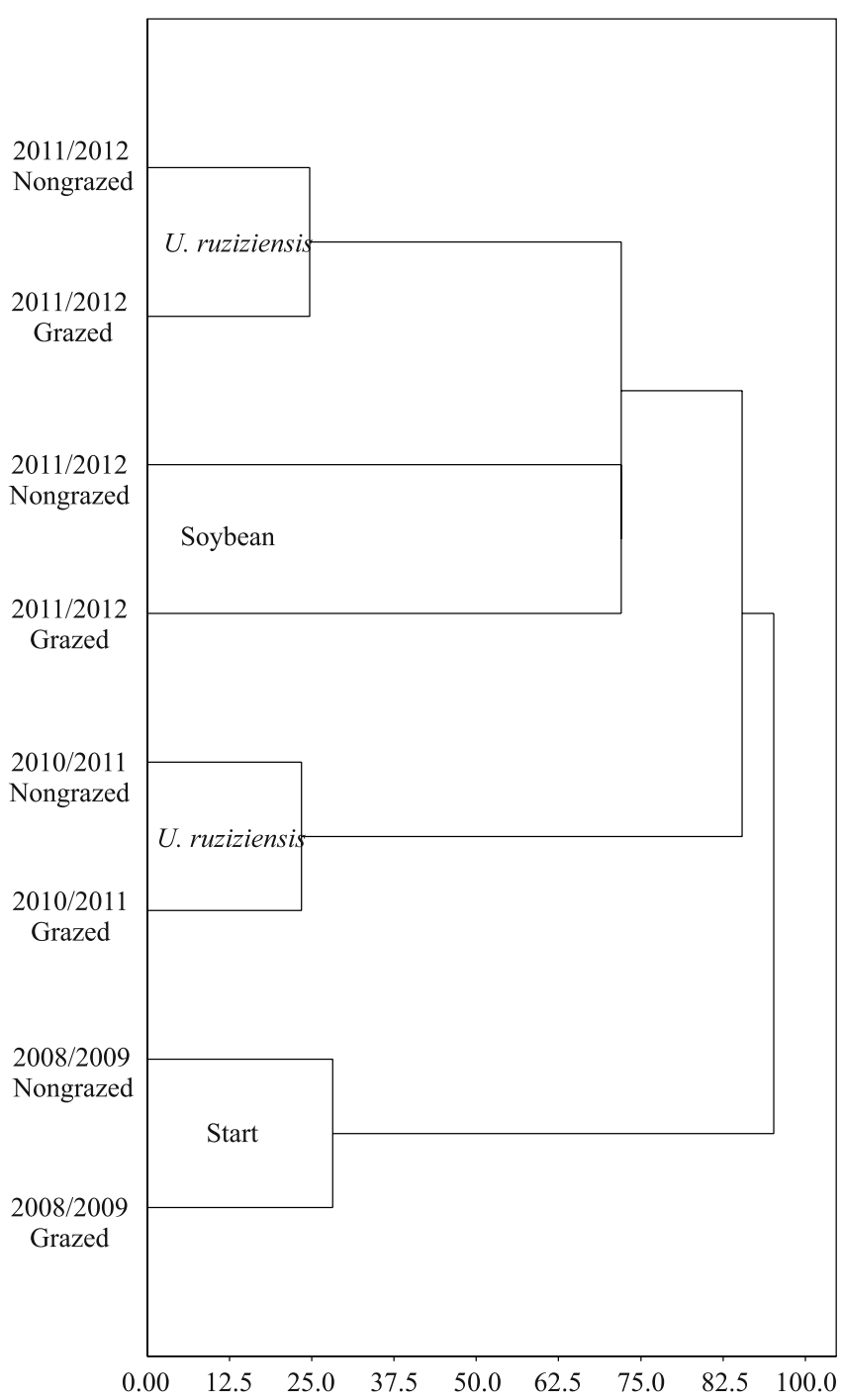

Figure 2. Cluster dendrogram by the complete linkage method, considering grazed and nongrazed areas, in an integrated crop-livestock system, in the Cerrado biome, for the following seasons: 2008/2009; post-brachiaria cultivation year 2010/2011; post-soybean cultivation year 2011/2012; and post-brachiaria cultivation year 2011/2012.

Pesq. agropec. bras., Brasília, v.53, n.11, p.1239-1247, Nov. 2018 DOI: 10.1590/S0100-204X2018001100006 
Soil physical data collected in the post-brachiaria cultivation year 2011/2012 were grouped with a shorter Euclidean distance (25\%), indicating similarity between treatments. These results reflect the implementation ICLS, by which the degraded area was recovered in the first two cycles (forage and soybean), both due to the presence of the animals and soil mobilization, and began to stabilize after the fourth harvest (postgrazing year 2011/2012). However, this result also indicates the importance of a continuous evaluation of the ICLS for the stress levels (animal trampling) that the system can withstand, mainly because the mobilized soil, associated to the high humidity, can favor soil compaction.

\section{Conclusions}

1. The integrated crop-livestock system with cattle grazing improves the soil physical properties, in comparison with the nongrazed areas, except for soil penetration resistance.

2. Soil aggregation, evaluated by the weighted mean diameter, is not altered by grazing, and correlates with the soil physical and biological properties.

3. The integrated crop-livestock system promotes the increase of the microbial biomass carbon and nitrogen, in comparison with the no-tillage system without animal grazing.

\section{References}

ALEF, K.; NANNIPIERI, P. (Ed.). Methods in applied soil microbiology and biochemistry. New York: Academic Press, 1995. 576p. DOI: 10.1016/B978-0-12-513840-6.X5014-9.

ANDERSON, T.-H.; DOMSCH, K.H. The metabolic quotient for $\mathrm{CO}_{2}\left(\mathrm{qCO}_{2}\right)$ as a specific activity parameter to assess the effects of environmental conditions, such as $\mathrm{pH}$ on the microbial biomass of forest soils. Soil Biology and Biochemistry, v.25, p.393-395, 1993. DOI: 10.1016/0038-0717(93)90140-7.

ASABE. American Society of Agricultural and Biological Engineers. Soil cone penetrometer. Saint Joseph, 2010. ASAE Standard S313.3.

BARTHRAM, G.T. Experimental techniques: the HFRO sward stick. In: THE HILL Farming Research Organization Biennial Report 1984-1985. Penicuik: HFRO, 1985. p.29-30.

BENGOUGH, A.G.; MCKENZIE, B.M.; HALLETT, P.D.; VALENTINE, T.A. Root elongation, water stress, and mechanical impedance: a review of limiting stresses and beneficial root tip traits. Journal of Experimental Botany, v.62, p.59-68, 2011. DOI: $10.1093 / \mathrm{jxb} / \mathrm{erq} 350$.
BONETTI, J. de A.; PAULINO, H.B.; SOUZA, E.D. de; CARNEIRO, M.A.C.; SILVA, G.N. da. Influência do sistema integrado de produção agropecuária no solo e na produtividade de soja e braquiária. Pesquisa Agropecuária Tropical, v.45, p.104112, 2015. DOI: 10.1590/1983-40632015v4529625.

BROOKES, P.C. The use of microbial parameters in monitoring soil pollution by heavy metals. Biology and Fertility of Soils, v.19, p.269-279, 1995. DOI: 10.1007/BF00336094.

CARVALHO, P.C. de F.; MORAES, A. de; PONTES, L. da S.; ANGHINONI, I.; SULC, R.M.; BATELLO, C. Definições e terminologias para Sistema Integrado de Produção Agropecuária. Revista Ciência Agronômica, v.45, p.1040-1046, 2014. Número especial. DOI: 10.1590/S1806-66902014000500020.

CLEGG, C.D. Impact of cattle grazing and inorganic fertiliser additions to managed grasslands on the microbial community composition of soils. Applied Soil Ecology, v.31, p.73-82, 2006. DOI: 10.1016/j.apsoil.2005.04.003.

CORBEELS, M.; MARCHÃO, R.L.; SIQUEIRA NETO, M.; FERREIRA, E.G.; MADARI, B.E.; SCOPEL, E.; BRITO, O.R. Evidence of limited carbon sequestration in soils under notillage systems in the Cerrado of Brazil. Scientific Reports, v.6, art.21450, 2016. DOI: 10.1038/srep21450.

DONAGEMA, G.K.; CAMPOS, D.V.B. de; CALDERANO, S.B.; TEIXEIRA, W.G.; VIANA, J.H.M. (Org.). Manual de métodos de análise de solo. 2.ed. rev. Rio de Janeiro: Embrapa Solos, 2011. 230p. (Embrapa Solos. Documentos, 132).

FRANZLUEBBERS, A.J.; SCHOMBERG, H.H.; ENDALE, D.M. Surface-soil responses to paraplowing of long-term notillage cropland in the Southern Piedmont USA. Soil and Tillage Research, v.96, p.303-315, 2007. DOI: 10.1016/j.still.2007.07.001.

FRANZLUEBBERS, A.J.; STUEDEMANN, J.A. Does grazing of cover crops impact biologically active soil carbon and nitrogen fractions under inversion or no tillage management? Journal of Soil and Water Conservation, v.70, p.365-373, 2015. DOI: 10.2489/jswc.70.6.365.

FRANZLUEBBERS, A.J.; STUEDEMANN, J.A.; FRANKLIN, D.H. Water infiltration and surface-soil structural properties as influenced by animal traffic in the Southern Piedmont USA. Renewable Agriculture and Food Systems, v.27, p.256-265, 2011. DOI: $10.1017 / \mathrm{S} 1742170511000378$.

FREITAS, P.L. de; LANDERS, J.N. The transformation of agriculture in Brazil through development and adoption of zero tillage conservation agriculture. International Soil and Water Conservation Research, v.2, p.35-46, 2014. DOI: 10.1016/S20956339(15)30012-5.

HAMMER, Ø.; HARPER, D.A.T.; RYAN, P.D. Past: paleontological statistics software package for education and data analysis. Palaeontologia Electronica, v.4, art.4, 2001.

JIANG, X.; WRIGHT, A.L.; WANG J.; LI, Z. Long-term tillage effects on the distribution patterns of microbial biomass and activities within soil aggregates. Catena, v.87, p.276-280, 2011. DOI: 10.1016/j.catena.2011.06.011.

JOZEFACIUK, G.; CZACHOR, H. Impact of organic matter, iron oxides, alumina, silica and drying on mechanical and water 
stability of artificial soil aggregates. Assessment of new method to study water stability. Geoderma, v.221-222, p.1-10, 2014. DOI: 10.1016/j.geoderma.2014.01.020.

LANDERS, J.N.; RASS, G.; FREITAS, P.L. de; BASCH, G.; GONZÁLEZ SANCHEZ, E.J.; TABAGLIO, V.; KASSAN, A.; DERPSCH, R.; FRIEDRICH, T. Effects of zero tillage (no-till) conservation agriculture on soil physical and biological properties and their contributions to sustainability. Geophysical Research Abstracts, v.15, EGU2013-11756, 2013.

LIMA, C.L.R. de; MIOLA, E.C.C.; TIMM, L.C.; PAULETTO, E.A.; SILVA, A.P. da. Soil compressibility and least limiting water range of a constructed soil under cover crops after coal mining in Southern Brazil. Soil and Tillage Research, v.124, p.190-195, 2012. DOI: 10.1016/j.still.2012.06.006.

LIMA, S.S. de; ALVES, J.B.R.; AQUINO, A.M. de; MERCANTE, F.M.; PINHEIRO, E.F.M.; SANT'ANNA, S.A.C.; URQUIAGA, S.; BODDEY, R.M. Relação entre a presença de cupinzeiros e a degradação de pastagens. Pesquisa Agropecuária Brasileira, v.46,p.1699-1706, 2011. DOI: 10.1590/S0100-204X2011001200016.

LOSS, A.; PEREIRA, M.G.; GIÁCOMO, S.G.; PERIN, A.; ANJOS, L.H.C. dos. Agregação, carbono e nitrogênio em agregados do solo sob plantio direto com integração lavourapecuária. Pesquisa Agropecuária Brasileira, v.46, p.1269-1276, 2011. DOI: 10.1590/S0100-204X2011001000022.

LOVELL, R.D.; JARVIS, S.C. Effects of urine on soil microbial biomass, methanogenesis, nitrification and denitrification in grassland soils. Plant and Soil, v.186, p.265-273, 1996. DOI: 10.1007/BF02415522.

MARTINS, A.P.; KUNRATH, T.R. ANGHINONI, I.; CARVALHO, P.C. de F. (Ed.). Integração soja-bovinos de corte no Sul do Brasil. 2.ed. Porto Alegre: UFGRS, 2015. 102p.

MORAES, A. de; CARVALHO, P.C. de F.; ANGHINONI, I.; LUSTOSAC, S.B.C.; COSTA, S.E.V.G. de A.; KUNRATH, T.R. Integrated crop-livestock systems in the Brazilian subtropics. European Journal of Agronomy, v.57, p.4-9, 2014a. DOI: 10.1016/j.eja.2013.10.004.

MORAES, M.T. de; DEBIASI, H.; CARLESSO, R.; FRANCHINI, J.C.; SILVA, V.R. da. Critical limits of soil penetration resistance in a Rhodic Eutrudox. Revista Brasileira de Ciência do Solo, v.38, p.288-298, 2014b. DOI: 10.1590/S0100-06832014000100029.
MUNIZ, L.C.; MADARI, B.E.; TROVO, J.B. de F.; CANTANHÊDE, I.S. de L.; MACHADO, P.L.O. de A.; COBUCCI, T.; FRANÇA, A.F. de S. Soil biological attributes in pastures of different ages in a croplivestock integrated system. Pesquisa Agropecuária Brasileira, v.46, p.1262-1268, 2011. DOI: 10.1590/S0100-204X2011001000021.

SANTOS, H.G. dos; JACOMINE, P.K.T.; ANJOS, L.H.C. dos; OLIVEIRA, V.A. de; LUMBRERAS, J.F.; COELHO, M.R.; ALMEIDA, J.A. de; CUNHA, T.J.F.; OLIVEIRA, J.B. de. Sistema brasileiro de classificação de solos. 3.ed. rev. e ampl. Brasília: Embrapa, 2013a. 353p.

SANTOS, M.E.R.; FONSECA, D.M. da; GOMES, V.M. Relações entre morfogênese e dinâmica do perfilhamento em pastos de capim-braquiária. Bioscience Journal, v.30, p.201-209, 2013 b.

SILVA, I.F.; MIELNICZUK, J. Avaliação do estado de agregação do solo afetado pelo uso agrícola. Revista Brasileira de Ciência do Solo, v.21, p.313-319, 1997.

SOUZA, E.D. de; COSTA, S.E.V.G. de A.; ANGHINONI, I.; CARVALHO, P.C. de F.; OLIVEIRA, E.V.F. de; MARTINS, A.P.; CAO, E.; ANDRIGHETTI, M. Soil aggregation in a croplivestock integration system under no-tillage. Revista Brasileira de Ciência do Solo, v.34, p.1365-1374, 2010a. DOI: 10.1590/ S0100-06832010000400033.

SOUZA, E.D. de; COSTA, S.E.V.G. de A.; ANGHINONI, I.; LIMA, C.V.S. de; CARVALHO, P.C. de F.; OLIVEIRA, E.V.F. de; MARTINS, A.P. Biomassa microbiana do solo em sistema de integração lavoura-pecuária em plantio direto, submetido a intensidades de pastejo. Revista Brasileira de Ciência do Solo, v.34, p.79-88, 2010b. DOI: 10.1590/S0100-06832010000100008.

TISDALL, J.M.; COCKROFT, B.; UREN, N.C. The stability of soil aggregates as affected by organic materials, microbial activity and physical disruption. Australian Journal of Soil Research, v.16, p.9-17, 1978. DOI: 10.1071/SR9780009.

UMER, M.I.; RAJAB, S.M. Correlation between aggregate stability and microbiological activity in two Russian soil types. Eurasian Journal of Soil Science, v.1, p.45-50, 2012.

VANCE, E.D.; BROOKES, P.C.; JENKINSON, D.S. An extraction method for measuring soil microbial biomass C. Soil Biological Biochemical, v.19, p.703-707, 1987. DOI: 10.1016/00380717(87)90052-6.

$\overline{\text { Received on April 6, } 2017 \text { and accepted on January 18, } 2018}$ 